November 2014

\title{
Will Kate Survive Kate? Review 1
}

Laura Starecheski

NPR Science Desk

Follow this and additional works at: http://ro.uow.edu.au/rdr

Part of the Audio Arts and Acoustics Commons, Australian Studies Commons, and the Psychiatric and Mental Health Commons

\section{Recommended Citation}

Starecheski, Laura, Will Kate Survive Kate? Review 1, RadioDoc Review, 1(2), 2014. doi:10.14453/ rdr.v1i2.2

Research Online is the open access institutional repository for the University of Wollongong. For further information contact the UOW Library: research-pubs@uow.edu.au 


\title{
Will Kate Survive Kate? Review 1
}

\begin{abstract}
To craft a narrative with a dramatic arc out of an onerous battle with illness, when no sure recovery is in sight: this was the task facing Will Kate Survive Kate? producer Masako Fukui when she set out to document a year in the life of 'Kate' - a 29-year-old Australian woman battling —and at times tightly holding on to-anorexia nervosa. Kate's family wants her to eat - to triumph over her illness - and for complicated and frustrating reasons, she can't bring herself to do it. For Kate, this is a matter of life and death. At the heart of Kate's story is the acknowledgment that none of us can control this will in each other, and an exploration of what happens when we try. The story lays bare the bonds between Kate and her family, allowing us to see their hope as something equally irrational as her illness - and also something we would all go to great lengths to preserve in their place. The largest challenge of Kate's story for the listener is that there is no 'why'. She is still making the small, incremental steps towards recovery, and is nowhere near the later stage of making meaning of her ordeal.
\end{abstract}

\section{Keywords}

anorexia, mental illness, personal narrative 


\title{
Will Kate Survive Kate?
}

\author{
Produced by Masako Fukui with technical production by Timothy Nicastri \\ for ABC RN 360 Documentaries (Australia, 2013). 50mins.
}

\section{Reviewer: Laura Starecheski}

Recovery from serious mental illness is a slow endeavour. Improvement is often incremental, barely noticeable to most people, including the person experiencing the illness: picture a road rising gradually in a monotonous landscape with few twists and turns and fewer landmarks. This is challenging terrain for storytellers. To craft a narrative with a dramatic arc out of an onerous battle with illness, when no sure recovery is in sight: this was the task facing Will Kate Survive Kate? producer Masako Fukui when she set out to document a year in the life of 'Kate', a 29-year-old Australian woman battling-and at times tightly holding on to-anorexia nervosa.

The resulting hour-long documentary begins with Kate addressing her eating disorder in two letters: one grateful (With you, I'm strong and committed.) and one resentful (I hate you. You manipulate me. You made me forget who I am.). We learn that it's been six weeks since Kate's most recent discharge from inpatient care, and that she hasn't eaten anything in about a month. The two letters bookend a family spat over a meal, the first true scene in the piece. Amid the clinking of forks on dishware, it's Kate against her parents. She insists the food on the table contains a certain calorie count and sugar content. This is how Kate argues her case for not eating, an attempt to assign some kind of rationality to something that her family will only ever see as irrational. We instantly feel the futility of trying to feed someone who cannot help but resist food. We also sense that whatever food means to someone without an eating disorder-the rest of the family, happily scraping away at their plates-it will likely never be that simple for Kate.

The documentary unfolds chronologically, and in a way the rest of the hour repeats the content of the opening scene, over and over: Kate's family wants her to eat-to triumph over her illness-and for complicated and frustrating reasons, she can't bring herself to do it. For Kate, this is a matter of life and death. We learn at one point that anorexia has the highest mortality rate of any mental illness ( $10 \%$ by some estimates), and that Kate has not eaten in six months. How she continues to survive is beyond understanding. It is bewildering to hear that her voice never sounds weak, even after half a year without food.

Listeners to Will Kate Survive Kate? spend an hour partly inside Kate's head, sometimes via diary entries read aloud, partly watching in horror from her family's vantage point. Fukui frames anorexia quite effectively as a condition affecting not just one person, but everyone who cares about them too. From Kate's twin sister, who lives in London, to 
her desperate mother, who breaks down at one point remembering how powerless she felt during Kate's first bout with her eating disorder, we feel the pain of her loved ones. We also hear, as in so many addiction stories, the loss of trust between family members - too much has been hidden, too many lies have been told. Kate's brother 'Tom' believes Kate has ulterior motives even when she is eating. Eating is just a way to get out of the hospital faster, he thinks, so she can go back to starving on her own terms as an outpatient.

A few distinct stylistic choices stood out to the American ears of this reviewer. First, the documentary is scored with non-instrumental music - that is, music including sung lyrics - a choice that I found distracting at best. At several moments where the voices of Kate or her family delicately carried an emotional revelation, a song with angst-ridden lyrics would swoop in, overpowering the scene and distancing the listener just when intimacy had been achieved. Second, the signposts that are so clear and blunt in most American radio documentary-who is speaking, visual descriptions of characters and places, where in time and space we are-are largely absent here, and so the listener is left swirling on the lip of a dark whirlpool with Kate, never quite sure what makes up the surrounding landscape.

The result is a hazy, torturous journey that allows the listener to experience anorexia through Kate's eyes-a success that necessarily makes for difficult listening. Sociologist Arthur Frank, writing on illness and storytelling, lays out several archetypes of 'illness narrative.' A 'restitution' story is one of regaining health: 'I was sick, but now I am / will be better.' (Frank 1995, p.98) In a 'quest' story, the sufferer makes use of the illness as a vehicle for personal transformation. Frank would call Kate's story a 'chaos narrative': 'there is no mediation, only immediacy. The body is imprisoned in the frustrated needs of the moment. The person living the chaos story has no distance from her life and no reflective grasp on it.' (Frank 1995, p.98) Over the course of the documentary, Kate goes into the hospital twice, once for almost one hundred days. And yet, she barely changes. Her behaviour and her mood are almost totally static throughout the documentary. As the sole expert in the piece, Dr. Janice Russell, a psychiatrist and physician, notes, treating patients with anorexia 'can be like watching grass grow' because 'they don't want to get better'.

This frustration comes through in the experience of listening to Will Kate Survive Kate? This may be purposeful, part of the nature of anorexia itself. Author Alice Gregory, recalling in The New Yorker her experience of the illness during college, writes, 'I can barely bring myself to think about this time, not because it depresses me but because it's so utterly dull.' (Gregory 2013) She notes that glamorised first-person stories of anorexia frequently become guidebooks for young girls seeking to emulate the behavior, and that the only 'truly radical' way to disrupt this cycle would be to 'show just how profoundly boring [anorexia] is-not sad or prurient or overdetermined.' (Gregory 2013) Fukui's close-up view of Kate's repetitive obsessions-eating a meal one 
green pea at a time; gorging on mints that happen to have diuretic effects-may act in service of this goal.

A close relative to a story like Kate's is the now-classic tale of recovery from drug addiction or alcoholism. These recovery narratives are typically told from a stable vantage point high above the preceding chaos, a safe place to look down from and detail the worst times. They tend to focus on the out-of-control years that led up to a rock bottom crash, delving into family history and whatever childhood events shaped the person at the centre of the story. The living out of the addiction, the person in the throes of the illness, is a rollercoaster ride-that's the thrill for the reader or the listener. But the recovery itself? In merciful examples of the form, it's a short, flat coast at the very end of the ride: 'And then I got better. Finally.' The 'how' of getting better isn't especially compelling (maybe this is why Fukui includes no treatment plan details from Kate's 98 days in the hospital), and neither is the daily battle to maintain equilibrium. What's interesting is the 'why.' Why am I like this? Why did I do the things I did? Why did I finally get better?

The largest challenge of Kate's story for the listener is that there is no 'why.' At times Kate does show insight into the mechanics of her illness, explaining that she 'was using food in an incorrect way', to control anxiety and depression, instead of as sustenance. As a listener, it's hard to know whether this is something Kate herself believes, or whether she's echoing the language of her treatment team. Either way, she is still making the small, incremental steps towards recovery, and is nowhere near the later stage of making meaning of her ordeal. We feel the effects of her illness head on: Kate describes wanting to die; the thrill of deceiving her family (having convinced them she's ingested more calories in the vehicle of powdered Ensure than she actually has, for instance); the shame of eating actual food. The result is that Kate in the throes of disease is the only Kate we ever meet.

At one point we learn that Kate has organised a party for an American singer named Amanda Palmer on tour in Australia-an event that's never fully explained. It's not clear if it's a private benefit concert, or just another stop on the tour, but we do learn that Kate likes Palmer's music, and the successful party is one of the only accomplishments she herself counts as a success. This makes sense-it's a moment where she is participating in life outside the hospital, glimpsing the world of health from the vantage point of illness. Most striking, though, is that this is also the only detail included about Kate's life apart from her eating disorder. We never meet any of her friends. We never learn what her job was, what she did during the time she was well, between ages 20 and 29. We never learn what her hobbies are, and what she likes and dislikes. This is a portrait of Kate-As-Disease. We are given almost no place to connect with Kate-thePerson, and this is unfortunate, because one would hope to leave a listening experience like this one with more understanding, and more empathy, and learning a bit about who Kate is apart from someone with anorexia could go a long way towards facilitating that. 
Some of the omissions were likely necessary. Kate's identity is obscured to protect her privacy and the privacy of her family. Other omissions may have been strategic. Fukui offers no physical description of Kate, no numbers that would let listeners know how much weight she lost, no record of how emaciated she might have become. Was this perhaps a way to avoid creating yet another 'guidebook' for aspiring anorexics? Or, an effort to hammer home the point that eating disorders are overall the stuff of our minds, not our bodies?

At the conclusion of the documentary, the listener is left at an optimistic point. Kate is discharged from the hospital, and we hear the family laughing together-a rare light moment in the hour. We learn that as an outpatient she still struggles with depression and anxiety, and wanting to use food, and control over what she eats, as a way to selfmedicate. But we sense that Kate has found some desire to live. Whether that will endure or not, it is something new.

If, as Arthur Frank writes, 'people who tell stories of illness are witnesses, turning illness into moral responsibility,' (Frank 1995, p.137) then what is the moral responsibility of the listener to Will Kate Survive Kate? Simply empathising with Kate, seeking to understand her? Is Fukui making a larger point about societal responsibility towards people with eating disorders? She suggests as much by confronting Kate's mother with a question about whether she feels it's fair for so much 'money out of the public purse' to be spent on treating people like Kate in intensive inpatient wards? (Kate's mother replies that Kate's illness should be treated just as cancer or other serious physical illness would be in intensive care-even if the prognosis isn't promising.)

Maybe the moral responsibility is to acknowledge the 'kingdom of illness', this 'nightside of life, a more onerous citizenship', as Susan Sontag writes (1978), as a place that all of us will visit at some point, sooner or later, whether through the experience of a loved one or through our own.Will Kate Survive Kate? brings us close to this dark place where death is nearby. In Kate's story, the will to rejoin the day-side of life is elusivesomething that may be more common than we like to acknowledge. I was left with an uncomfortable moral question, one echoed in other stories of addiction, sometimes depression, and physical illness too: how do we care for someone who is 'sick', and who does not want to be healthy again? Do we always assume their desire is wrong, because it is destructive and painful? At the heart of Kate's story is the acknowledgment that none of us can control this will in each other, and an exploration of what happens when we try. The story lays bare the bonds between Kate and her family, allowing us to see their hope as something equally irrational as her illness-and also something we would all go to great lengths to preserve in their place. 


\section{References}

Frank, Arthur (1995), The Wounded Storyteller, Chicago: Chicago University Press. http://dx.doi.org/10.7208/chicago/9780226260037.001.0001

Gregory, Alice (2013), “Anorexia, the Impossible Subject”, The New Yorker, December 11, 2013.

Sontag, Susan (1978), IIIness as Metaphor, New York: Farrar, Straus and Giroux.

PODCAST of Will Kate Survive Kate available here on ABC RN 360 Documentaries website

LAURA STARECHESKI reports on health for NPR's Science Desk. She was previously a staffer at NPR's State of the Re:Union (SOTRU) and freelanced for The World, Latino USA and elsewhere. Her 2006 Radiolab story 'Goat on a Cow' won a Third Coast Silver Award for Best Documentary, and SOTRU's 'The Hospital Always Wins' won a 2014 National Edward R. Murrow award. Laura was a 2012 Rosalynn Carter Fellow for Mental Health Journalism and 2014 Knight-Wallace Fellow at the University of Michigan. She serves on the board of AIR (The Association of Independents in Radio).

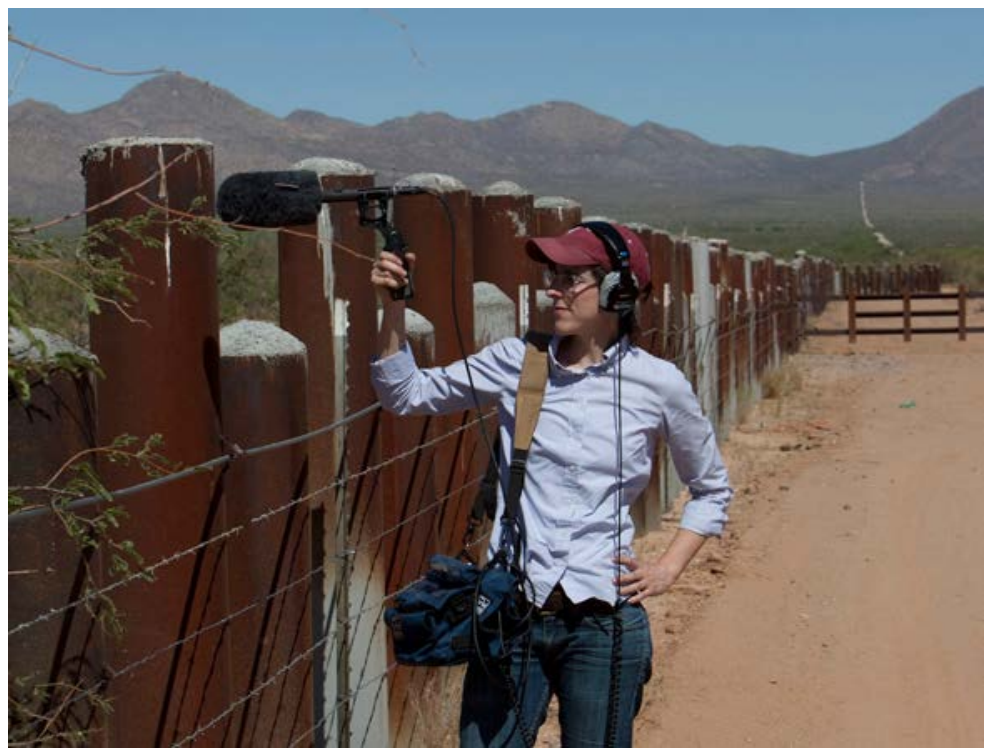

Reporting at the US / Mexico border. photo: Bob Torrez 